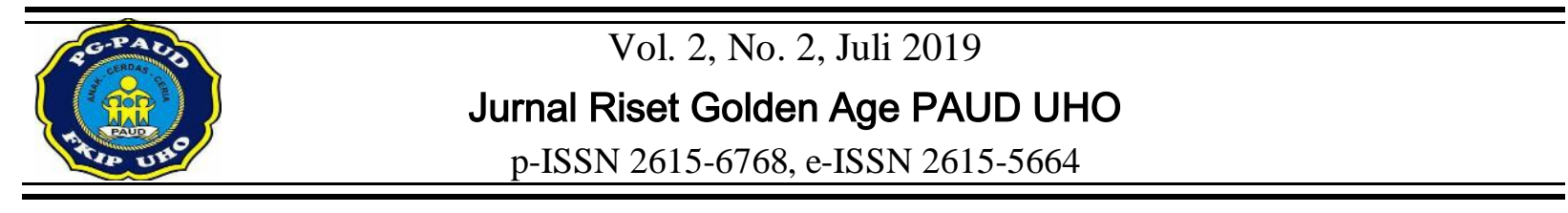

\title{
MENINGKATKAN KEMAMPUAN INTERPERSONAL ANAK MELALUI KEGIATAN
} BERCERITA PENGALAMAN

\author{
Yulianti $^{1)}$, Harlin Yusuf ${ }^{1)}$ \\ ${ }^{1}$ Jurusan PG-PAUD, Universitas Halu Oleo. Jln. H.E.A Mokodompit, Kendari 93232, Indonesia.
}

\begin{abstract}
Abstrak
Penelitian ini bertujuan untuk meningkatkan kemampuan interpersonal anak melalui kegiatan bercerita pengalaman di Kelompok A RA Wildaanun Rabbaniyyun Kendari. Subjek dalam penelitian ini adalah anak didik kelompok A RA Wildaanun Rabbaniyyun Kendari, yang berjumlah 13 orang yang terdiri dari 7 anak laki-laki dan 6 anak perempuan dengan rentang usia 4-5 tahun. Jenis penelitian ini adalah penelitian tindakan kelas yang dilaksanakan dalam dua siklus. Pengumpulan data dalam penelitian ini menggunakan metode observasi, wawancara dan dokumentasi. Hasil observasi aktivitas mengajar guru pada siklus I diperoleh persentase ketercapaian sebesar 51,14\% atau 8 aspek yang tercapai sedangkan pada siklus II mengalami peningkatan sebesar $85,71 \%$ atau 12 aspek yang tercapai. Aktivitas belajar anak siklus I diperoleh persentase ketercapaian sebesar 76,92\%, atau 9 aspek yang tercapai sedangkan pada siklus II mengalami peningkatan sebesar $92,86 \%$ atau 13 aspek yang tercapai. Hasil belajar anak berupa peningkatan kemampuan interpersonal melalui kegiatan bercerita pengalaman sebelum dilakukan tindakan sebesar $46,15 \%$ kemudian meningkat pada siklus I sebesar 76,92\% dan pada siklus II hasil belajar anak didik meningkat sebesar 92,31\%.
\end{abstract}

Kata Kunci: Interpersonal, Anak, Bercerita Pengalaman.

\section{IMPROVING CHILDREN'S INTERPERSONAL SKILLS TROUGH ACTIVITIES THAT TELL STORIES}

\begin{abstract}
This Research aims to improve children's interpersonal skills trough activities that tell stories in group A RA Wildaanun Rabbaniyyun, Kendari. The subjects in this research were students in group A of RA Wildaanun Rabbaniyyun Kendari, totaling of 13 children consisting of 7 boys and 6 girl students with range age 4-5 year old. The results of observation of teacher teaching activities in the first cycle obtained an achievement percentage of $51.14 \%$ or 8 aspects achieved while in the second cycle increased by $85.71 \%$ or 12 aspects while. Learning activities of children incycle I obtained an achievement percentage of $76.92 \%$ or 9 aspects achieved while in cycle II there was an increase of $92.86 \%$ or 13 aspects which. Children's learning outcomes in the form of increasing interpersonal skills trough activities to tell stories before an action is carried out by $46.15 \%$. Then increased in the first cycle of $76.92 \%$ and in the second cycle studeent's learning outcomes increased by $92.31 \%$.
\end{abstract}

Keywords: Interpersonal, Child, Storytelling.

\section{PENDAHULUAN}

Anak usia dini adalah seorang anak yang usianya dibawah enam tahun yang masih mengalami masa pertumbuhan untuk mencapai perkembangan selanjutnya. Menurut Montessori dalam Yuliani (2010:20) menyatakan bahwa usia keemasan merupakan masa dimana anak mulai peka untuk menerima berbagai stimulasi dan berbagai upaya pendidikan dari lingkungannya baik disengaja maupun tidak disengaja. Pada masa peka inilah terjadi pematangan fungsi fisik dan psikis sehingga anak siap merespon dan mewujudkan semua tugas perkembangan yang diharapkan muncul pada pola perilakunya sehari-hari.

Suyadi \& Ulfah (2012:17). Anak usia dini adalah sebagai penerus untuk generasi mendatang. Anak harus diberikan rangsangan dan metode pembelajaran yang baik dan benar 
untuk mewujudkan tercapainya generasi yang sukses. Anak usia dini adalah sosok individu yang sedang menjalani proses perkembangan dengan pesat dan fundamental bagi kehidupan selanjutnya, sehingga pada masa ini anak usia dini disebut masa keemasan (golden age), masa ini adalah masa dimana otak anak mengalami perkembangan yang paling cepat dalam pertumbuhannya. Daya serap otak anak dapat diibaratkan seperti sebuah spons (karet busa) yang cepat menyerap air.

Howard Gardner dalam Yaumi, (2012: 12) menetapkan ada 9 jenis kecerdasan majemuk yaitu kecerdasan bahasa, kecerdasan logik-matematik, kecerdasan visual-spasial, kecerdasan kinestetik, kecerdasan musikal, kecerdasan interpersonal, kecerdasan intrapersonal, kecerdasan naturalis, kecerdasan eksistensial dan kecerdasan interpersonal.

Salah satu kemampuan perkembangan anak usia dini yang harus ditingkatkan yaitu perkembangan interpersonal anak. Kemampuan interpersonal adalah kemampuan menciptakan, membangun dan mempertahankan suatu hubungan antar pribadi (sosial) yang sehat dan saling menguntungkan.

Kecerdasan Interpersonal adalah kemampuan untuk menjalin hubungan sosial dengan orang lain. Kecerdasan interpersonal adalah kemampuan anak dalam menjalin komunikasi secara efektif, mampu berempati secara baik, dan kemampuan mengembangkan hubungan yang harmonis dengan orang lain.

Safaria, (2005: 23-24). Kemampuan interpersonal yang kuat menempatkan kita untuk kesuksesan sebaliknya kemampuan interpersonal yang lemah akan menghadapkan kita pada rasa frustasi dan kegagalan terus menerus dan keberhasilan kita, kalaupun ada terjadi secara kebetulan saja.

Kemampuan interpersonal memungkinkan kita untuk bisa memahami berkomunikasi dengan orang lain, melihat perbedaan dalam mood, temperamen, motivasi dan kemampuan. Termasuk juga kemampuan untuk membentuk dan juga menjaga hubungan, serta mengetahui berbagai perasaan yang terdapat dalam suatu kelompok, baik sebagai anggota maupun sebagai pemimpin (Cambell, 2006: 172).

Williams (2005: 162) mengungkapkan bahwa kemampuan interpersonal adalah kemampuan untuk memahami dan berinteraksi dengan baik dengan orang lain. Kemampuan ini melibatkan kemampuan verbal dan nonverbal, kemampuan kerjasama, menagemen konflik, strategi membangun konsensus, kemampuan untuk percaya, menghormati, memimpin dan memotivasi orang lain untuk mencapai tujuan umum.

Amstrong (2005: 21), kemampuan interpersonal adalah kemampuan untuk memahami dan bekerja dengan orang lain, kemampuan interpersonal mencakup kemampuan membaca orang atau menilai orang lain, kemampuan berteman, dan keterampilan berinteraksi dengan orang dalam lingkungan baru.

May, dkk (2008: 197) menyatakan bahwa kemampuan interpersonal adalah kemampuan untuk berhubungan dengan orang-orang di sekitar kita. Kecerdasan ini adalah kemampuan untuk memahami dan memperkirakan perasaan, temperamen, suasana hati, maksud dan keinginan orang lain dan menanggapinya secara layak.

Dari beberapa pendapat para ahli diatas dapat disimpulkan bahwa kemampuan interpersonal merupakan kecakapan atau keterampilan yang dimiliki oleh seseorang dalam hubungannya dengan orang lain, kecakapan atau keterampilan untuk berkomunikasi baik verbal maupun non verbal.

Berdasarkan observasi awal yang dilakukan di RA Wildaanun Rabbaniyyun Kendari menunjukan bahwa kemampuan interpersonal anak belum menjadi bagian pembiasaan karena sekolah lebih menekankan pada kemampuan nilai-nilai agama dan moral anak. Bertitik tolak pada paparan permasalahan tersebut, maka perlu dirancang suatu metode pembelajaran yang menarik bagi anak untuk meningkatkan kemampuan interpersonal anak. Peneliti merasa perlu untuk menggunakan metode bercerita pengalaman.

Bachir (2005: 10), bercerita adalah menuturkan sesuatu yang mengisahkan tentang perbuatan, pengalaman suatu kejadian yang sungguh-sungguh terjadi maupun yang rekaan belaka. Dhieni, (2005: 6.3) bercerita adalah suatu kegiatan yang dilakukan seseorang secara lisan kepada orang lain dengan alat peraga atau tanpa alat tentang apa yang harus disampaikan dalam bentuk pesan, informasi atau hanya sebuah dongeng yang untuk didengarkan dengan rasa menyenangkan, oleh karena itu orang yang menyajikan cerita tersebut harus menyampaikannya dengan menarik.

Hibanah Rahman dalam Sari, (2014: 21) cerita adalah penggambaran tentang sesuatu 
secara verbal. Melalui bercerita anak diajak berkomunikasi, berfantasi, berkhayal dan mengembangkan kognisinya.

Bercerita merupakan suatu stimulus yang dapat membangkitkan anak terlibat secara mental. Melalui cerita, aktivitas mental anak dapat melambung, melanglang buana melampaui isi cerita itu sendiri. Bercerita adalah suatu kegiatan yang dilakukan seseorang untuk menyampaikan suatu pesan, informasi atau sebuah dongeng belaka, yang biasa dilakukan secara lisan atau tertulis. Cerita anak adalah "tuturan lisan, karya bentuk tulis atau pementasan tentang suatu kejadian, peristiwa dan sebagainya yang terjadi diseputar dunia anak (Musfiroh, 2005: 59).

Bercerita adalah menuturkan sesuatu yang mengisahkan tentang perbuatan atau sesuatu kejadian dan disampaikan secara lisan dengan tujuan membagikan pengalaman dan pengetahuan kepada orang lain (Bachri :2005:10).

Dari beberapa pendapat para ahli diatas dapat ditarik kesimpulan bahwa bercerita pengalaman merupakan Bercerita adalah menuturkan sesuatu yang mengisahkan tentang perbuatan, pengalaman atau sesuatu kejadian yang sungguh-sungguh terjadi maupun yang rekaan belaka.

\section{METODE}

Jenis penelitian yang digunakan dalam penelitian ini adalah Penelitian Tindakan Kelas (PTK). Menurut Wijaya Kusumah dan Dedi Dwitagama (2012: 9) penelitian tindakan kelas (PTK) adalah penelitian yang dilakukan oleh guru di kelasnya sendiri dengan cara merencanakan, melaksanakan, merefleksikan tindakan secara kolaboratif dan partisipan dengan tujuan memperbaiki kinerja sebagai guru, sehingga hasil belajar siswa dapat meningkat.

Penelitian ini dilaksanakan pada Kelompok A RA Wildaanun Rabbaniyyun Kendari.. Penelitian dilaksanakan pada tanggal 03 September 2018 sampai 13 September 2018. Subjek dalam penelitian ini adalah guru dan anak didik yang berjumlah 13 orang yang terdiri atas 6 anak laki-laki dan 7 anak perempuan dengan rentang usia 4-5 tahun.

Adapun faktor-faktor yang diteliti dan diamati dalam penelitian ini adalah: a) faktor anak didik, mengamati aktivitas kegiatan belajar dalam meningkatkan kemampuan interpersonal anak melalui kegiatan bercerita pengalaman dan b) faktor guru, mengamati aktivitas kegiatan mengajar dalam meningkatkan kemampuan interpersonal anak melalui kegiatan bercerita pengalaman.

Pengumpulan data dalam penelitian ini dihimpun melalui hasil observasi, dokumentasi dan wawancara. Observasi adalah suatu teknik yang dapat dilakukan guru untuk mendapatkan berbagai informasi atau data tentang peremabangan dan permasalahan anak. Melalui pengamatan, guru dapat mengetahui perkembangan yang terjadi pada anak dalam kurun waktu tertentu . Observasi dilakukan oleh guru Kelompok B sebagai observer dengan menggunakan lembar observasi. Penggunaan lembar observasi ini untuk melihat proses pelaksanaan pembelajaran yang dilaksanakan oleh guru ketika melakukan kegiatan pengelompokkan benda untuk meningkatkan kemampuan kognitif anak. Dokumentasi yaitu mencari data mengenai hal-hal atau variable yang berupa catatan, transkrip, buku, surat kabar, majalah, prasasti, notulen rapat, lengger, agenda dan sebagainya (Arikunto, 2010: 274). Dokumentasi ini berupa foto guru/peneliti pada saat proses meneliti sebagai bukti dalam melakukan kegiatan penelitian di lapangan. Wawancara adalah suatu tehnik pengumpulan data yang dapat dilakukan guru untuk mendapatkan informasi tentang perkembangan dan permasalahan anak dengan cara melakukan percakapan langsung, baik dengan anak maupun orang tua.

Analisis data merupakan cara yang dilakukan untuk mengetahui keefektifan suatu metode dalam kegiatan pembelajaran (Aqib, 2009:203). Pengelolaan data dalam penelitian ini disesuaikan dengan teknik penilaian di TK yaitu dengan menggunakan tanda sebagai berikut: Belum Berkembang $(\mathrm{BB})=*$, Mulai Berkembang $(\mathrm{MB})=* *$, Berkembang Sesuai Harapan $=* * *$, Berkembang Sangat Baik $=* * * *$ (Depdiknas, 2004: 26).

Tabel 1. Kategori Keberhasilan Klasikal

\begin{tabular}{ccc}
\hline Persentase & Kategori & Simbol \\
\hline $95 \%-100 \%$ & $(\mathrm{BSB})$ & $* * * *$ \\
\hline $85 \%-94 \%$ & $(\mathrm{BSH})$ & $* * *$ \\
\hline $75 \%-84 \%$ & $(\mathrm{MB})$ & $* *$ \\
\hline$<75 \%$ & $(\mathrm{BB})$ & $*$ \\
\hline
\end{tabular}

Indikator kinerja dalam penelitian ini terdiri dari indikator proses pembelajaran dan indikator hasil (nilai) anak didik. Dari segi indikator proses pembelajaran, tindakan 
dikatakan berhasil apabila minimal $85 \%$ proses pelaksanaan tindakan sesuai dengan skenario pembelajaran, baik yang dilakukan oleh guru maupun anak didik. Dari segi indikator hasil, tindakan dikatakan berhasil apabila anak didik telah mencapai nilai berkembang sesuai harapan (BSH) dan berkembang sangat baik (BSB) minimal $85 \%$ baik secara individual maupun klasikal.

\section{HASIL DAN PEMBAHASAN}

Penelitian dilakukan dengan tindakan siklus I yang terdiri dari 4 kali pertemuan dan mengikuti empat tahapan kegiatan yaitu perencanaan, pelakanaan tindakan, observasi dan evaluasi, dan refleksi. Hal-hal yang dilakukan dalam tahap ini adalah menyiapkan RPPH dan RPPM, media yang dibutuhkan, lembar observasi anak dan guru serta alat evaluasi/penilaian.

Pertemuan I dilaksanakan pada hari Senin, 3 September 2018 pada pukul 07.3010.30 WITA dengan tema "Rekreasi", subtema "tempat-tempat rekreasi", tema spesifik pantai. Indikator yang harus dicapai oleh anak pada pertemuan pertama adalah anak dapat berkomunikasi ramah dengan temannya. Pada pertemuan 1, terdapat 3 anak yang bersedia bercerita pengalaman di depan kelas.

Kegiatan sebelum pembelajaran, didahului dengan apel pagi/berbaris di halaman sekolah, ibu guru memberi arahan untuk berbaris dengan rapi, anak bernyanyi bersama dan memeriksa kuku anak didik, membaca hadist dan membaca do'a-do'a sehari-hari. Anak didik masuk ke dalam kelas, memberi salam dan membaca do'a. Anak didik duduk di karpet bersiap-siap untuk dzikir bersama dan muraja'ah (membaca do'a-do'a sehari-hari, hadist-hadist dan surah-surah pendek dalam Al-Qur'an). Ibu guru kelas membimbing anak untuk membaca dzikir pagi bersama dan muraja'ah. Selanjutnya, anak didik bersiap-siap untuk membaca iqro' dan membaca permulaan. Disela-sela anak didik menunggu giliran membaca iqro' dan membaca permulaan, peneliti/guru mengajak anak bermain bongkar pasang (balok-balok).

Pada kegiatan inti pembelajaran sesuai rancangan RPPH yang ada, terfokus pada judul penelitian peneliti yaitu mengajak anak bercerita pengalamannya di depan kelas. Kemudian, guru mengamati bagaimana reaksi anak-anak lain mendengarkan cerita pengalaman dari temannya, sehingga dapat mengetahui sejauh mana kemampuan interpersonal anak.
Setelah istrahat dilanjutkan dengan kegiatan akhir meliputi kegiatan tanya jawab mengenai kegiatan yang telah dilaksanakan yaitu guru meminta anak menyebutkan cerita pengalaman dari teman-temannya yang telah bercerita. Kemudian, guru mengulangi kembali apa yang telah diceritakan anak untuk memperkuat pemahaman anak. Selanjutnya, membaca do'a sebelum pulang dan memberi salam.

Pada pertemuan I, kemampuan anak dalam bercerita masih kurang memperhatikan, belum teratur susunan bahasa dalam bercerita dan perhatian teman-teman yang lain terhadap temannya yang bercerita masih kurang mendengarkan sehingga isi cerita dari temannya tidak dipahami.

Pertemuan II dilaksanakan pada hari Selasa, 4 September 2018 pada pukul 07.3010.30 WITA sesuai tema "Rekreasi" dengan subtema "tempat-tempat rekreasi" tema spesifik taman budaya. Adapun indikator yang harus dicapai oleh anak pada pertemuan kedua adalah anak dapat menyimak dengan perhatian tentang cerita temannya. Sebelum proses kegiatan belajar mengajar di kelas dimulai, seluruh anak didik melaksanakan apel pagi/berbaris di halaman sekolah, ibu guru memberi arahan untuk berbaris dengan rapi, anak bernyanyi bersama, membaca hadist dan membaca do'ado'a sehari-hari. Anak didik masuk ke dalam kelas, memberi salam dan membaca do'a. Anak didik duduk di karpet bersiap-siap untuk dzikir bersama dan muraja'ah (membaca do'a-do'a sehari-hari, hadist-hadist dan surah-surah pendek dalam Al-Qur'an). Ibu guru kelas membimbing anak untuk membaca dzikir pagi bersama dan muraja'ah. Selanjutnya, anak didik bersiap-siap untuk membaca iqro' dan membaca permulaan. Disela-sela anak didik menunggu giliran membaca iqro' dan membaca permulaan, peneliti/guru mengajak anak bermain bongkar pasang (balok-balok).

Pada kegiatan inti pembelajaran sesuai rancangan RPPH yang ada, terfokus pada judul penelitian peneliti/guru mengajak anak bercerita pengalamannya di depan kelas. Kemudian, guru mengamati bagaimana reaksi anak-anak setelah mendengarkan cerita pengalaman dari temannya, sehingga dapat mengetahui sejauh mana kemampuan interpersonal anak.

Setelah istrahat dilanjutkan dengan kegiatan akhir meliputi kegiatan tanya jawab mengenai kegiatan yang telah dilaksanakan yaitu guru meminta anak menyebutkan cerita 
pengalaman dari teman-temannya. Selanjutnya, guru mengulangi kembali apa yang telah diceritakan anak kemudian membaca do'a sebelum pulang dan memberi salam.

Pada pertemuan II, kemampuan anak dalam bercerita mulai berkembang, mulai memperhatikan, susunan bahasa dalam bercerita mulai teratur dan perhatian teman-teman yang lain terhadap temannya yang bercerita mulai diperhatikan sehingga isi cerita dari temannya mulai dipahami.

Pertemuan III dilaksanakan pada hari Rabu, 5 September 2018 pada pukul 07.3010.30 WITA sesuai tema "Rekreasi" dengan subtema "tempat-tempat rekreasi", tema spesifik kebun binatang. Adapun indikator yang harus dicapai oleh anak pada pertemuan ketiga adalah anak dapat memberi perhatian yang baik pada isi cerita teman. Sebelum proses kegiatan belajarmengajar di kelas dimulai, seluruh anak didik melaksanakan apel pagi/berbaris di halaman sekolah, ibu guru memberi arahan untuk berbaris dengan rapi, anak bernyanyi bersama, membaca hadist dan membaca do'a-do'a seharihari. Anak didik masuk ke dalam kelas, memberi salam dan membaca do'a. Anak didik duduk di karpet bersiap-siap untuk dzikir bersama dan muraja'ah (membaca do'a-do'a sehari-hari, hadist-hadist dan surah-surah pendek dalam Al-Qur'an). Ibu guru kelas membimbing anak untuk membaca dzikir pagi bersama dan muraja'ah. Selanjutnya, anak didik bersiap-siap untuk membaca iqro' dan membaca permulaan.

Pada kegiatan inti pembelajaran sesuai rancangan RPPH yang ada, terfokus pada judul penelitian peneliti/guru mengajak anak bercerita pengalamannya di depan kelas. Kemudian, guru mengamati bagaimana reaksi anak-anak setelah mendengarkan cerita pengalaman dari temannya, sehingga dapat mengetahui sejauh mana kemampuan interpersonal anak.

Setelah istrahat dilanjutkan dengan kegiatan akhir meliputi kegiatan tanya jawab mengenai kegiatan yang telah dilaksanakan yaitu guru meminta anak menyebutkan cerita pengalaman dari teman-temannya. Selanjutnya, guru mengulangi kembali apa yang telah diceritakan anak kemudian membaca do'a sebelum pulang dan memberi salam.

Pada pertemuan III, kemampuan anak dalam bercerita mulai berkembang, mulai memperhatikan, susunan bahasa dalam bercerita mulai teratur dan perhatian teman-teman yang lain terhadap temannya yang bercerita mulai diperhatikan sehingga isi cerita dari temannya mulai dipahami.

Pertemuan IV dilaksanakan pada hari Kamis, 6 September 2018 pada pukul 07.3010.30 WITA sesuai tema "Rekreasi" dengan subtema "tempat-tempat rekreasi", tema spesifik waterpark. Adapun indikator yang harus dicapai oleh anak pada pertemuan keempat ini adalah anak dapat menceritakan pengalaman sesuai isi cerita. Sebelum proses kegiatan belajarmengajar di kelas dimulai, seluruh anak didik melaksanakan apel pagi/berbaris di halaman sekolah, ibu guru memberi arahan untuk berbaris dengan rapi, anak bernyanyi bersama, membaca hadist dan membaca do'a-do'a seharihari. Anak didik masuk ke dalam kelas, memberi salam dan membaca do'a. Anak didik duduk di karpet bersiap-siap untuk dzikir bersama dan muraja'ah (membaca do'a-do'a sehari-hari, hadist-hadist dan surah-surah pendek dalam Al-Qur'an). Ibu guru kelas membimbing anak untuk membaca dzikir pagi bersama dan muraja'ah. Selanjutnya, anak didik bersiap-siap untuk membaca iqro' dan membaca permulaan.

Pada kegiatan inti pembelajaran sesuai rancangan RPPH yang ada, terfokus pada judul penelitian peneliti/guru mengajak anak bercerita pengalamannya di depan kelas. Kemudian, guru mengamati bagaimana reaksi anak-anak setelah mendengarkan cerita pengalaman dari temannya, sehingga dapat mengetahui sejauh mana kemampuan interpersonal anak.

Setelah istrahat dilanjutkan dengan kegiatan akhir meliputi kegiatan tanya jawab mengenai kegiatan yang telah dilaksanakan yaitu guru meminta anak menyebutkan cerita pengalaman dari teman-temannya. Selanjutnya, guru mengulangi kembali apa yang telah diceritakan anak kemudian membaca do'a sebelum pulang dan memberi salam.

Pada pertemuan IV, kemampuan anak dalam bercerita mulai berkembang, mulai memperhatikan, susunan bahasa dalam bercerita mulai teratur, komunikasi antar teman mulai ramah dan perhatian teman-teman yang lain terhadap temannya yang bercerita mulai diperhatikan sehingga isi cerita dari temannya mulai dipahami.

Selama proses pembelajaran berlangsung, guru sebagai observer mengamati jalannya pembelajaran dengan menggunakan lembar observasi untuk guru dan lembar observasi untuk anak. Kegiatan observasi dilakukan 
bersamaan dengan pelaksanaan tindakan untuk setiap pertemuan pada siklus I.

Hasil observasi guru sesuai dengan pedoman lembar observasi sebanyak 14 aspek yang harus dicapai guru. Pada siklus I aspek yang dicapai guru sebanyak 8 aspek atau sebesar 51,14\%. Aspek yang diamati diantaranya yaitu: (1) guru mempersiapkan anak untuk belajar; (2) guru menyiapkan alat dan bahan pembelajaran; (3) guru melakukan apersepsi yang berhubungan dengan tema/subtema pembelajaran; (4) guru menjelaskan materi pembelajaran sesuai tema kegiatan yang akan dilaksanakan berkenaan dengan kegiatan bercerita pengalaman; (5) guru meminta anak untuk mengerjakan tugas yang diberikan; (6) guru memberikan bimbingan kepada anak saat kegiatan bercerita pengalaman; (7) guru mengadakan tanya jawab mengenai kegiatan yang telah dilakukan; (8) guru meminta anak untuk menyebutkan kembali materi, serta kegiatan apasaja yang telah dilakukan.

Sedangkan aspek yang tidak tercapai terdiri atas 6 aspek yaitu (1) guru memotivasi anak untuk rajin belajar, (2) guru meminta anak untuk memperhatikan kegiatan yang akan dilakukan, (3) guru memberi kesempatan kepada anak untuk mengajukan pertanyaan mengenai materi ataupun hal-hal yang akan dilakukan apabila belum dipahami, (4) guru memantau anak dalam kelas saat anak melakukan kegiatan pembelajaran, (5) guru bertanya tentang masalah-masalah yang dihadapi anak saat melakukan kegiatan bercerita pengalaman dan (6) guru memberikan kesimpulan terhadap kegiatan yang dilakukan hari ini dan melakukan bimbingan bernyanyi serta berdoa sebelum pulang. Untuk lebih jelasnya dapat dilihat pada diagram berikut:

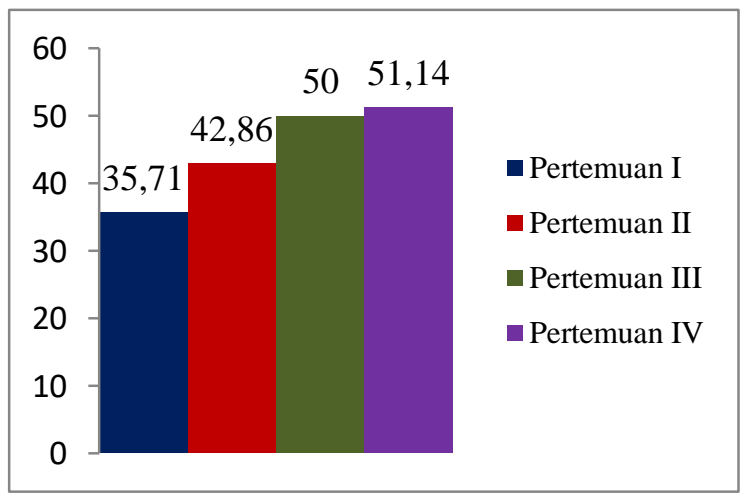

Gambar 1. Diagram Hasil Analisis Aktivitas Mengajar Guru Siklus I
Hasil analisis observasi anak sesuai dengan lembar observasi pada siklus I yaitu sebanyak 14 aspek yang diamati dan dicapai, namun yang tercapai sebanyak 9 aspek atau sebesar 64,29\% diantaranya: (1) anak mempersiapkan diri untuk belajar; (2) perhatian anak tertuju pada guru; (3) anak memperhatikan penjelasan materi pembelajaran berkenaan dengan kegiatan bercerita pengalaman; (4) anak mendengarkan bimbingan dan arahan yang diberikan oleh guru; (5) anak berkomunikasi dengan teman; (6) anak bekerjasama dengan teman; (7) anak memiliki rasa empati; (8) anak menjalin hubungan yang baik dengan teman; (9) anak bernyanyi dan berdoa sebelum pulang.

Sedangkan yang tidak tercapai sebanyak 5 aspek atau sebesar 35,71\% diantaranya: (1) anak menyanyikan lagu-lagu sesuai tema; (2) anak aktif memperhatikan apersepsi yang berkenaan dengan tema/ subtema pembelajaran; (3) anak mendengarkan motivasi untuk rajin belajar; (4) anak dapat melaksanakan tugasnya sampai selesai dengan waktu yang telah ditentukan dan (5) Anak memberikan simpulan terhadap kegiatan yang telah dilakukan. Untuk lebih jelasnya dapat dilihat pada diagram berikut:

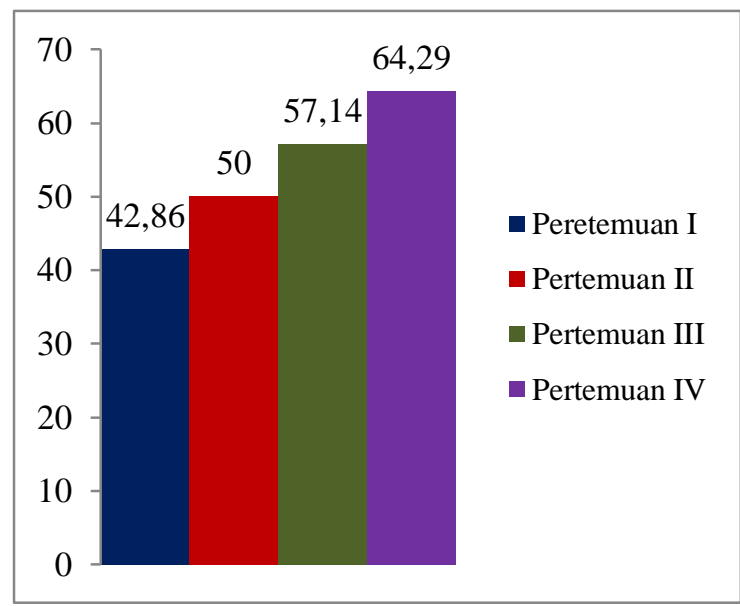

Gambar 2. Diagram Hasil Analisis Aktivitas Belajar Anak Didik Siklus I

Tabel 1. Nilai Klasikal pada Siklus I

\begin{tabular}{|c|c|c|}
\hline Kategori & $\begin{array}{c}\text { Jumlah } \\
\text { Anak }\end{array}$ & $\begin{array}{c}\text { Persentase } \\
(\%)\end{array}$ \\
\hline $\begin{array}{l}\text { Berkembang Sangat } \\
\text { Baik }\end{array}$ & 4 & 30,77 \\
\hline $\begin{array}{l}\text { Berkembang Sesuai } \\
\text { Harapan }\end{array}$ & 5 & 38,46 \\
\hline Mulai Berkembang & 4 & 30,77 \\
\hline Belum Berkembang & 0 & 0 \\
\hline Jumlah & 13 & 100 \\
\hline
\end{tabular}


Berdasarkan hasil yang diperoleh pada Tabel 1. terlihat bahwa secara klasikal kegiatan meningkatkan kemampuan interpersonal anak melalui kegiatan bercerita pengalaman sebagian besar anak sudah dapat melaksanakan kegiatan dengan baik yaitu 69,23\% anak memperoleh nilai BSB dan BSH namun belum mencapai indikator kinerja yang ditetapkan yaitu $85 \%$ anak memperoleh nilai BSB dan BSH. Oleh karena itu, guru dan peneliti mendiskusikan kekurangan-kekurangan apa saja yang terdapat pada pelaksanaan tindakan siklus I untuk kemudian diperbaiki dan dilaksanakan pada siklus II.

Dari hasil observasi, maka beberapa hal yang harus diperbaiki adalah membuat suasana belajar senyaman mungkin, agar anak bisa leluasa bercerita dengan penuh rasa percaya diri, aktif dan ekspresif.

Pertemuan I dilaksanakan pada hari Senin, 10 September 2018 pada pukul 07.1510.30 WITA sesuai tema "Rekreasi" dengan subtema "Perlengkapan rekreasi", tema spesifik tikar. Adapun indikator yang harus dicapai oleh anak pada pertemuan pertama adalah anak dapat berkomunikasi ramah dengan temannya. Sebelum proses kegiatan belajar-mengajar di kelas dimulai, seluruh anak didik melaksanakan apel pagi/berbaris di halaman sekolah, ibu guru memberi arahan untuk berbaris dengan rapi, anak bernyanyi bersama dan memeriksa kuku anak didik, membaca hadist dan membaca do'ado'a sehari-hari. Anak didik masuk ke dalam kelas, memberi salam dan membaca do'a. Anak didik duduk di karpet bersiap-siap untuk dzikir bersama dan muraja'ah (membaca do'a-do'a sehari-hari, hadist-hadist dan surah-surah pendek dalam Al-Qur'an). Ibu guru kelas membimbing anak untuk membaca dzikir pagi bersama dan muraja'ah. Selanjutnya, anak didik bersiap-siap untuk membaca iqro' dan membaca permulaan. Disela-sela anak didik menunggu giliran membaca iqro' dan membaca permulaan, peneliti/guru mengajak anak menulis dan mewarnai gambar.

Pertemuan I siklus II, anak sudah mulai antusias dalam menceritakan pengalamannya, komunikasi dengan teman sudah tidak canggung lagi, mulai tanya jawab tentang kegiatan yang dilakukan saat liburan, perhatian mulai tertuju pada cerita teman yang bercerita sehingga mereka merasakan apa yang dirasakan oleh temannya saat liburan.
Pertemuan II dilaksanakan pada hari Selasa, 11 September 2018 pada pukul 07.3010.30 WITA sesuai tema "Rekreasi" dengan subtema "perlengkapan rekreasi", tema spesifik pakaian. Adapun indikator yang harus dicapai oleh anak pada pertemuan kedua adalah anak dapat menyimak dengan perhatian cerita temannya. Sebelum proses kegiatan belajarmengajar di kelas dimulai, seluruh anak didik melaksanakan apel pagi/berbaris di halaman sekolah, ibu guru memberi arahan untuk berbaris dengan rapi, anak bernyanyi bersama, membaca hadist dan membaca do'a-do'a seharihari. Anak didik masuk ke dalam kelas, memberi salam dan membaca do'a. Anak didik duduk di karpet bersiap-siap untuk dzikir bersama dan muraja'ah (membaca do'a-do'a sehari-hari, hadist-hadist dan surah-surah pendek dalam Al-Qur'an). Ibu guru kelas membimbing anak untuk membaca dzikir pagi bersama dan muraja'ah. Selanjutnya, anak didik bersiap-siap untuk membaca iqro' dan membaca permulaan. Disela-sela anak didik menunggu giliran membaca iqro' dan membaca permulaan, peneliti/guru mengajak anak menggambar bebas.

Pertemuan II siklus II, anak sudah mulai antusias dalam menceritakan pengalamannya, komunikasi dengan teman sudah tidak canggung lagi, mulai menyimak apa yang diceritakan temannya, mulai tanya jawab tentang kegiatan yang dilakukan saat liburan, perhatian mulai tertuju pada cerita teman yang bercerita sehingga mereka merasakan apa yang dirasakan oleh temannya saat liburan.

Pertemuan III dilaksanakan pada hari Rabu, 12 September 2018 pada pukul 07.3010.30 WITA sesuai tema "Rekreasi" dengan subtema "perlengkapan rekreasi", tema spesifik makanan. Adapun indikator yang harus dicapai oleh anak pada pertemuan ketiga adalah anak dapat memberi perhatian yang baik pada isi cerita temannya. Sebelum proses kegiatan belajar-mengajar di kelas dimulai, seluruh anak didik melaksanakan apel pagi/berbaris di halaman sekolah, ibu guru memberi arahan untuk berbaris dengan rapi, anak bernyanyi bersama, membaca hadist dan membaca do'ado'a sehari-hari. Anak didik masuk ke dalam kelas, memberi salam dan membaca do'a. Anak didik duduk di karpet bersiap-siap untuk dzikir bersama dan muraja'ah (membaca do'a-do'a sehari-hari, hadist-hadist dan surah-surah pendek dalam Al-Qur'an). Ibu guru kelas membimbing anak untuk membaca dzikir pagi 
bersama dan muraja'ah. Selanjutnya, anak didik bersiap-siap untuk membaca iqro' dan membaca permulaan. Disela-sela anak didik menunggu giliran membaca iqro' dan membaca permulaan, peneliti/guru mengajak anak untuk mendengarkan cerita.

Pertemuan III siklus II, anak sudah mulai antusias dalam menceritakan pengalamannya, komunikasi dengan teman sudah mulai ramah, mulai menyimak apa yang diceritakan temannya, mulai tanya jawab tentang kegiatan yang dilakukan saat liburan, perhatian mulai tertuju pada cerita teman yang bercerita sehingga mereka merasakan apa yang dirasakan oleh temannya saat liburan.

Pertemuan IV dilaksanakan pada hari Kamis, 13 September 2018 pada pukul 07.3010.30 WITA sesuai tema "Rekreasi" dengan subtema "Perlengkapan rekreasi" tema spesifik minuman. Adapun indikator yang harus dicapai oleh anak pada pertemuan keempat adalah anak dapat menceritakan pengalamannya. Sebelum proses kegiatan belajar-mengajar di kelas dimulai, seluruh anak didik melaksanakan apel pagi/berbaris di halaman sekolah, ibu guru memberi arahan untuk berbaris dengan rapi, anak bernyanyi bersama, membaca hadist dan membaca do'a-do'a sehari-hari. Anak didik masuk ke dalam kelas, memberi salam dan membaca do'a. Anak didik duduk di karpet bersiap-siap untuk dzikir bersama dan muraja'ah (membaca do'a-do'a sehari-hari, hadist-hadist dan surah-surah pendek dalam Al-Qur'an). Ibu guru kelas membimbing anak untuk membaca dzikir pagi bersama dan muraja'ah. Selanjutnya, anak didik bersiap-siap untuk membaca iqro' dan membaca permulaan. Disela-sela anak didik menunggu giliran membaca iqro' dan membaca permulaan, peneliti/guru mengajak anak untuk mendengarkan cerita.

Pertemuan IV siklus II, anak semakin antusias dalam menceritakan pengalamannya, komunikasi dengan teman sudah ramah, mulai menyimak apa yang diceritakan temannya, mulai tanya jawab tentang kegiatan yang dilakukan saat liburan, perhatian mulai tertuju pada cerita teman yang bercerita sehingga mereka merasakan apa yang dirasakan oleh temannya saati liburan.

Selama proses pembelajaran berlangsung, guru sebagai observer mengamati jalannya pembelajaran dengan menggunakn lembar observasi untuk guru dan lembar observasi untuk anak. Kegiatan observasi dilakukan bersamaan dengan pelaksanaan tindakan untuk setiap pertemuan pada siklus II.

Hasil observasi guru sesuai dengan pedoman lembar observasi sebanyak 14 aspek yang harus dicapai guru. Pada siklus II aspek yang dicapai guru sebanyak 12 aspek atau sebesar 85,71\%. Aspek yang diamati diantaranya yaitu: (1) guru mempersiapkan anak untuk belajar; (2) guru menyiapkan alat dan bahan pembelajaran; (3) guru melakukan apersepsi yang berhubungan dengan tema/subtema pembelajaran; (4) guru menjelaskan materi pembelajaran sesuai tema kegiatan yang akan dilaksanak berkenaan dengan kegiatan bercerita pengalaman; (5) guru memberikan bimbingan kepada anak saat kegiatan bercerita pengalaman; (6) guru mengadakan tanya jawab mengenai kegiatan yang telah dilakukan; (7) guru meminta anak untuk menyebutkan kembali materi, serta kegiatan apasaja yang telah dilakukan, (8) guru memotivasi anak untuk rajin belajar, (9) guru meminta anak untuk memperhatikan kegiatan yang akan dilakukan, (10) guru memberi kesempatan kepada anak untuk mengajukan pertanyaan mengenai materi ataupun hal-hal yang akan dilakukan apabila belum dipahami, (11) guru memantau anak dalam kelas saat anak melakukan kegiatan pembelajaran, (12) guru bertanya tentang masalah-masalah yang dihadapi anak saat melakukan kegiatan bercerita pengalaman.

Sedangkan yang tidak tercapai adalah (1) guru memberikan kesimpulan terhadap kegiatan yang dilakukan hari ini dan melakukan bimbingan bernyanyi serta berdoa sebelum pulang dan (2) guru meminta anak untuk memperhatikan kegiatan yang akan dilakukan. Untuk lebih jelasnya dapat dilihat pada diagram berikut:

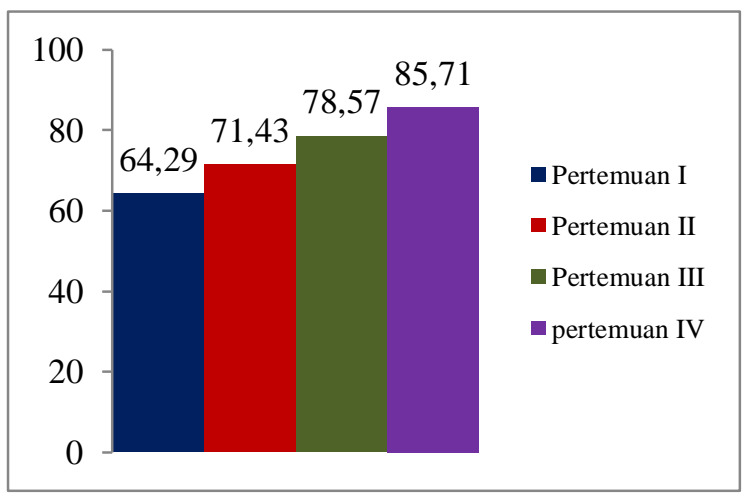

Gambar 3. Diagram Hasil Analisis Aktivitas Mengajar Guru Siklus II 
Analisis hasil observasi anak sesuai dengan lembar observasi pada siklus II yaitu sebanyak 14 aspek yang diamati dan dicapai, namun yang tercapai sebanyak 13 aspek atau sebesar 92,86\% diantaranya: (1) anak mempersiapkan diri untuk belajar; (2) perhatian anak tertuju pada guru; (3) anak memperhatikan penjelasan materi pembelajaran berkenaan dengan kegiatan bercerita pengalaman; (4) anak mendengarkan bimbingan dan arahan yang diberikan oleh guru; (5) anak berkomunikasi dengan teman; (6) anak bekerjasama dengan teman; (7) anak memiliki rasa empati; (8) anak menjalin hubungan yang baik dengan teman; (9) anak bernyanyi dan berdoa sebelum pulang; (10) anak aktif memperhatikan apersepsi yang berkenaan dengan tema/ subtema pembelajaran; (11) anak mendengarkan motivasi untuk rajin belajar; (12) anak dapat melaksanakan tugasnya sampai selesai dengan waktu yang telah ditentukan dan (13) anak memberikan simpulan terhadap kegiatan yang telah dilakukan. Sedangkan yang tidak tercapai sebanyak 1 aspek atau sebesar $7,14 \%$ yaitu anak menyanyikan lagu-lagu sesuai tema. Untuk lebih jelasnya dapat dilihat pada diagram berikut:

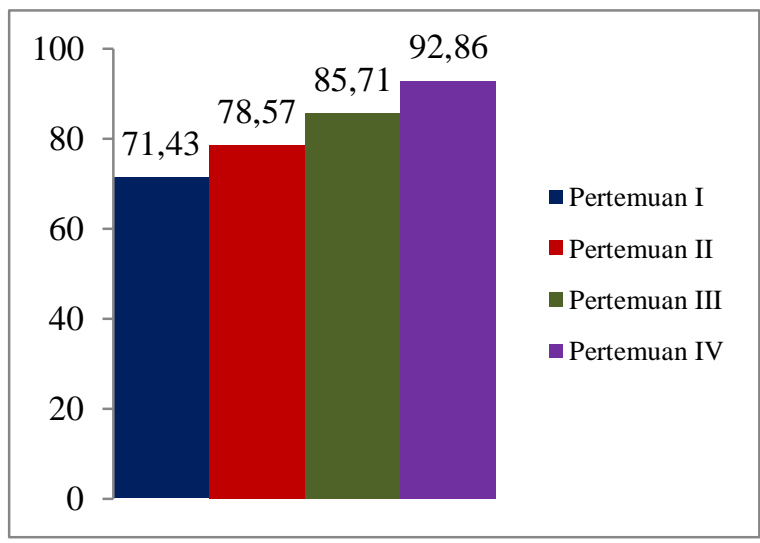

Gambar 4. Diagram Hasil Analisis Aktivitas Belajar Anak Didik Siklus II

Tabel 2. Nilai Klasikal pada Siklus II

\begin{tabular}{lcc}
\hline \multicolumn{1}{c}{ Kategori } & $\begin{array}{c}\text { Jumlah } \\
\text { Anak }\end{array}$ & $\begin{array}{c}\text { Persentase } \\
(\%)\end{array}$ \\
\hline $\begin{array}{l}\text { Berkembang } \\
\text { Sangat Baik }\end{array}$ & 8 & 53,85 \\
\hline $\begin{array}{l}\text { Berkembang Sesuai } \\
\text { Harapan }\end{array}$ & 9 & 38,46 \\
\hline Mulai Berkembang & 3 & 7,69 \\
\hline Belum Berkembang & 0 & 0 \\
\hline Jumlah & 20 & 100 \\
\hline
\end{tabular}

Berdasarkan data hasil perolehan nilai anak didik yang ditampilkan pada Tabel 2, maka dapat disimpulkan bahwa secara klasikal perolehan nilai anak didik dalam kegiatan meningkatkan kemampuan interpersonal anak melalui kegiatan bercerita pengalaman pada Kelompok B mengalami peningkatan, karena tingkat keberhasilan anak didik yaitu sebesar 85\% memperoleh nilai $\mathrm{BSH}$ dan $\mathrm{BSB}$, dapat dikatakan bahwa sebagian besar anak didik dipandang telah mampu menyelesaikan tugastugas yang telah ditetapkan sesuai dengan indikator penilaian dalam penelitian ini khususnya dalam pelaksanaan tindakan siklus II.

Jika dilihat dari pemahaman anak didik mulai dari pelaksanaan siklus I sebesar 76,92\% jika dibandingkan pada tahapan observasi awal/prasiklus penelitian yang hanya mencapai $46,15 \%$ dan pada tindakan siklus II mencapai persentase sebesar 92,31\%, menunjukkan hasil yang lebih baik dari sebelumnya, karena indikator kinerja yang ditetapkan telah tercapai yaitu minimal $85 \%$ maka peneliti dan guru sepakat bahwa penelitian ini dapat dihentikan sampai pada siklus II.

\section{SIMPULAN DAN SARAN}

\section{Kesimpulan}

Berdasarkan analisis data hasil observasi aktivitas mengajar guru pada siklus I diperoleh hasil mengajar guru pada siklus I dari 14 aspek yang diamati hanya 8 aspek yang dicapai oleh guru dengan persentase ketercapaian sebesar $51,14 \%$ sedangkan yang tidak terlaksana sebanyak 6 aspek atau sebesar 42,86\%. Aktivitas belajar anak pada siklus I dari 14 aspek yang diamati hanya 9 aspek yang dicapai oleh anak dengan persentase ketercapaian sebesar $64,29 \%$ sedangkan yang tidak terlaksana sebanyak 5 aspek atau sebesar $35,71 \%$. Pada siklus II presentase ketercapaian aktivitas mengajar guru mengalami peningkatan sebanyak 12 aspek dengan presentase $85,71 \%$ dan aktivitas guru yang tidak tercapai sebanyak 2 aspek dengan presentase $14,29 \%$, sedangkan presentase keberhasilan ketercapaian aktivitas belajar anak didik juga mengalami peningkatan sebanyak 13 aspek dengan presentase 92,86\% dan aktivitas belajar anak yang tidak tercapai sebanyak 1 aspek atau sebesar 7,14\%.

\section{Saran}

Setelah melaksanakan tindakan penelitian maka peneliti menyarankan hal-hal diantaranya dalam pelaksanaan pembelajaran maka 
hendaknya mempertimbangkan materi, media, dan strategi yang tepat untuk anak didik dan guru dituntut untuk selalu kreatif dan inovatif dalam melaksanakan kegiatan-kegiatan yang dapat meningkatkan potensi anak didik.

\section{DAFTAR PUSTAKA}

Amstrong, Thomas. 2005. Setiap Anak Cerdas. Jakarta: Gramedia Pustaka.

Aqib, Zainal. 2009. Penelitian Tindakan Kelas. Bandung: CV. Yrama Widya.

Arikunto, Suharsimi. 2010. Prosedur Penelitian Suatu Pendekatan Praktek. Jakarta: Rineka Cipta.

Bachri S. Bahtiar. 2005, Pengembangan Kegiatan Bercerita Di Taman KanakKanak Teknik dan Prosedurnya, Jakarta: Departemen Pendidikan Nasional.

Champbell, L. (2006). Metode Praktis Pembelajaran Berbasis Multiple Intelligence (Alih bahasa: Tim Intuisi). Depok: Intuisi Press.

Depdiknas. 2004. Pedoman Penilaian di Taman Kanak-Kanak. Jakarta: Depdiknas.

Djamarah, Syaeful Bahri. 2005. Guru dan Anak Didik dalam Interaksi Anak Didik. Jakarta: Rineka Cipta.

Dhieni Nurbiana .2005. Metode Pengembangan Bahasa. Jakarta : Universitas Terbuka.

Hoerr, Thomas R. 2007. Buku Kerja Multiple Intellegence. Bandung: Kaifa MZN.

Kusumah, Wijaya, dkk. 2012. Mengenal Penelitian Tindakan Kelas Edisike II. Jakarta: PT. Indeks

May, Lwin, dkk. 2008. How to Multiply Your Child's Intelligence: Cara Mengembangkan Berbagai Kecerdasan. Yogyakarta: Indeks.

Musfiroh, Takdiroatun. 2005. Bercerita Untuk Anak Usia Dini. Jakarta: Depdiknas.

Safaria, 2005. Interpersonal Intellegence. Sleman: Amara Books.

Sari, Novtrya Meta. 2014. Meningkatkan Kemampuan Berbahasa Anak melalui Metode Bercerita di Kelompok B TK Yasporbi. Bengkulu: Universitas Bengkulu.
Ulfah, Maulidya \& Suyadi. 2012. Konsep Dasar PAUD. Bandung.

Williams E, Evelyn. 2005. Mengajar Dengan Empati. Bandung: Penerbit Nuansa.

Yaumi, Muhammad. 2012. Pembelajaran Berbasis Multiple Intelligences. Jakarta: Dian Rakyat.

Yuliani, Nurani Sujiono. 2010. Konsep Dasar Pendidikan Anak Usia Dini. Jakarta: Indeks. 